石油技術協会誌 第 66 巻 第 6 号（平成13年11月）

JOURNAL OF THE JAPANESE ASSOCIATION FOR PETROLEUM TECHNOLOGY

VOL. 66, NO. 6 (Nov., 2001)

\begin{abstract}
解 説
基礎試錐「南海トラフ」におけるメタンハイドレートの探鉱*

高橋 秀明**・米澤 哲夫*** ・武富 義和 ${ }^{* * * *}$

(Received July 26, 2001 ; accepted November 9 2001)

\section{Exploration for natural hydrate in Nankai-Trough wells offshore Japan}

Hideaki Takahashi, Tetsuo Yonezawa and Yoshikazu Takedomi

Abstract: Exploration for natural methane hydrate was carried out in the Nankai-Trough offshore Japan at a water depth of $945 \mathrm{~m}$ over an 88 day period, from November 1999 to February 2000. This was a national project led by Ministry of International Trade and Industry (MITI) to seek a new energy source. It was organized by Japan National Oil Corporation (JNOC) in collaboration by Japan Petroleum Exploration Co., Ltd as the drilling operator. The Nankai-Trough well was drilled with R \& B Falcon's deepwater semisubmersible, the "M. G. Hulme, Jr.". The location was selected where BSR (Bottom Simulating Reflector) is the clearest on the seismic section. Six wells within $100 \mathrm{~m}$ distances were drilled through the BSR horizon and the hydrate rich formation was confirmed between $1,135 \mathrm{~m}$ to $1,213 \mathrm{~m}$ BMSL (below mean sea level). This paper describes the planning, preparatory phase and the challenging operations.
\end{abstract}

Key words : hydrate, deepwater, offshore, exploration, Nankai-Trough

\section{1.はじめに}

大水深下あるいは永久凍土下の堆積物中に存在するメ タンハイドレートは，その資源量が従来型の油・ガスの 約 2 倍あるといわれ, 次世代エネルギ一源として期待さ れている $\left(\right.$ Kvenvolden $\left.^{1)}\right)$ 。とりわけ，油・ガスの生産 に乏しくかつ深海に囲まれた日本では，それに早くから 着目し, 通産省（当時）は1995年度を初年度とする「第 8 次国内石油および可燃性天然ガス資源開発 5 力年計

*平成 13 年 5 月 1 日, Offshore Technology Conference にて講演 This paper was presented at OTC2001 (Offshore Technology Conference) in Houston on May 1, 2001 and published as OTC 13040. The authors were permitted by OTC to publish its Japanese version onto the Journal of the JAPT under the copyright of OTC.

**石油資源開発侏) Japan Petroleum Exploration Co., Ltd.

***石油公団 Japan National Oil Corporation

****経済産業省 Ministry of Economy, Trade and Industry

Copyright (C) 2001, JAPT
画」の一環として，その最終年度となる1999年度に日本 周辺海域でメタンハイドレート層を掘削して資源として の可能性を調查することを決定した。石油公団は直ちに その実施体制を整備し，民間会社を率いて準備作業を開 始した。

掘削地点は, すでに科学者達によってメタンハイド レートの存在が示されていた南海トラフ海域に決められ (Satoh. et al. ${ }^{2}$, Ashi. et al. $\left.{ }^{3)}\right) ， 1996$ 年と1997年に同海域 で実施された震探作業の結果, 静岡県天竜川河口沖合約 $50 \mathrm{~km}$ ，水深 $950 \mathrm{~m}$ の地点が選定された（図 1 ）。ここで は，震探断面図においてハイドレートの存在を示唆する BSR (Bottom Simulating Reflector) が海面下 1,240 m 相当のところに明瞭に確認されている（図 2 )。図 3 は, メタンハイドレートが存在しえる温度圧力条件の領域 （実線の左下側）を示したものであるが, 本井で予想さ れる地層温度（破線）之深度約 $1,240 \mathrm{~m}$ で交わること 加らしてあ，震探断面図に見られた約 $1,240 \mathrm{~m}$ の BSR は八イドレート層の基底を示すすのであろうと思われ た。

なお，本井では，浅部のハイドレート層を調查した 
後, そのまま深部の油・ガスの探鉱をも兼ねるという計 画であった。そのため, 本ロケーションは BSR だけで なく, 樑部に油・ガスのポテンシャルをむつ第三紀の構 造も備える地点が選定され, 掘削深度は海面下 $2,800 \mathrm{~m}$ と計画された。

本稿では, この世界初のメタンハイドレート探鉱プロ ジェクトとなった基礎試錐「南海トラフ」について, 計 画と準備から実作業と結果に至るまでを掘削オペレー

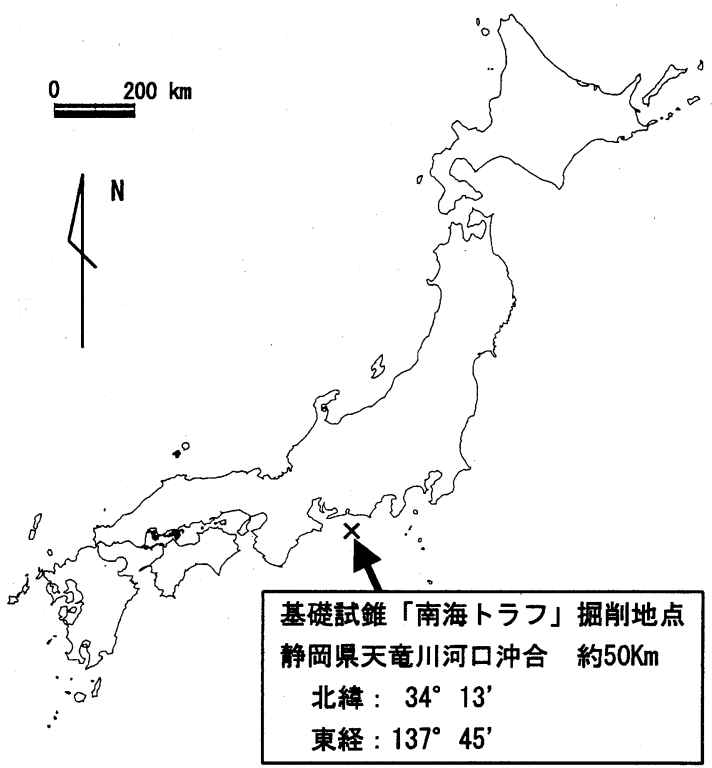

図 1 ロケーションマップ
ションの視点から報告する。

なお，本稿は，2001年 5 月 1 日ヒューストンでの OTC 2001 において同著者が発表した「Exploration for Natural Hydrate in Nankai-Trough Wells Offshore Japan (OTC 13040)」の, 著者による邦訳である。 OTC の許可を得て石油技術協会誌に掲載するむので, 著作権は OTCにある。

\section{2. 共同研究「メタンハイドレート開発技術」}

1995年, 本プロジェクトが具体化した直後, 石油公団 TRC (Technology Research Center) は民間10社を率 いて 5 カ年計画の共同研究「メタンハイドレート開発技 術」を立ち上げた。その目的は, 基礎試錐「南海トラ フ」の掘削で最大の成果が得られるべく技術的な準備を 行うことである。ここでは, ハイドレートの存在と量を どのような手段を使ってどう評価するか, またメタンハ イドレートの分解・生成のメカニズムなどが精力的に研 究された。その中で掘削グループが研究した主な課題 4 つを下に紹介する $\left(\right.$ Ohara $\left.^{4)}\right)$ 。

\section{1 掘削泥水}

大水深掘削では通常, 泥水中にハイドレートが生成さ れないように注意を払う。ハイドレートができると坑口 装置などに問題が生じるからである。そのため, 泥水中 に 10〜15 wt\%の NaCl や 5〜10 wt\%のグリコールを 混入するなどして, 坑内をハイドレートが安定して存在 できない環境にする。ところが，八イドレート層を掘進 する場合は, 地層中のハイドレートが溶けないように注

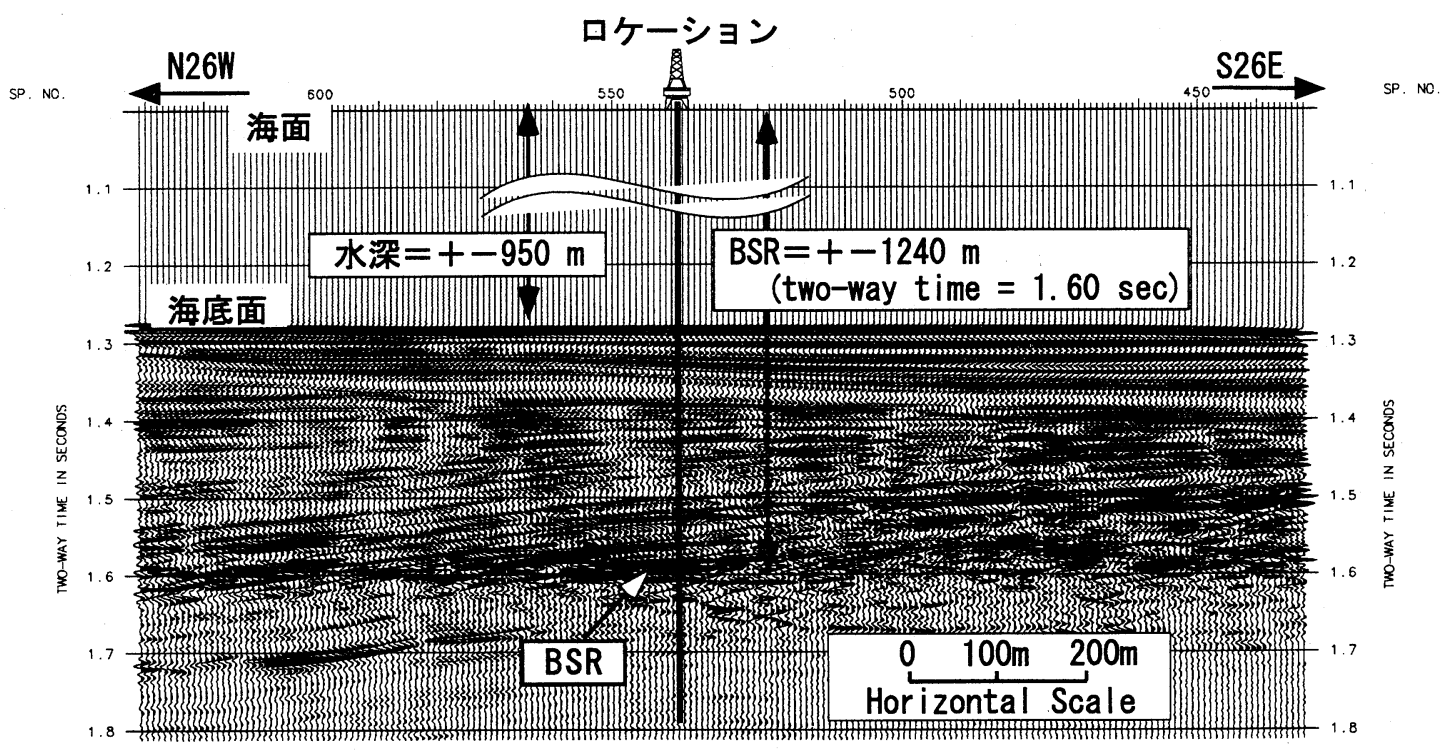

図 2 震探断面図 


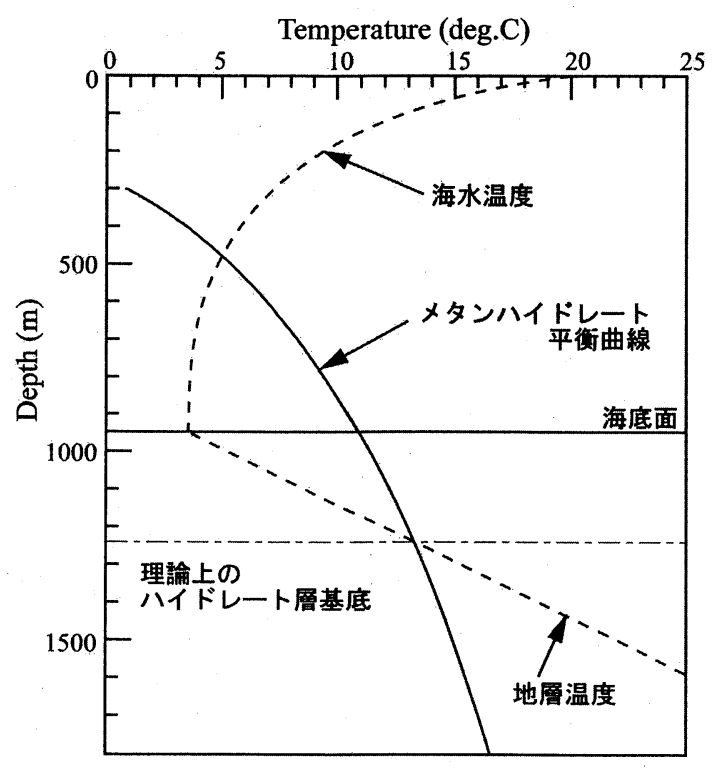

図 3 メタンハイドレート平衡曲線と予想地層温度

意を払わなくてはならない。ハイドレートが溶けると， ガスが発生して危険な状況になったり，坑が崩れたり， コアがうまく回収できなかったりするからである。それ には坑内を，ハイドレートが安定して存在できる環境に しなくてはならない。これらの相反する 2 つの条件を満 たすため, ハイドレートの速度論的安定性が研究された (Maeda. et al. ${ }^{5)}$, Okui. et al. ${ }^{6)}$ )。すなわち，ハイドレー トの生成む分解も時間的に遅くさせる効果をあつ添加剂 の選定実験が繰り返された。Lecithin, Polyvinylpyrrolidone (PVP), および Polyvinylcaprolactam (PVCap) などを比較した結果, PVCap が最も効果的 であることが分かった。結論として, 基礎試錐「南海卜 ラフ」のハイドレート層掘削には, $0.6 \mathrm{wt} \%$ の PVCap を混入した $\mathrm{NaCl} / \mathrm{KCl} /$ Polymer 泥水を使うことにし た。低温でのレオロジー特性に問題ないことも実験で確 認した。

\section{2 泥水冷却システム}

たとえ PVCap を混入した泥水を使用したとしても， またハイドレート層をケーシングで隠したとしても, 泥 水温度がハイドレートを分解するのに十分高温であれ ば，ハイドレート層は溶けて問題を起こす。それを解決 するため, 泥水冷却システムが設計された（Ichikawa. et $\left.a l .{ }^{7)}\right)$ 。

最初に設計されたシステムは，ハイドレート層深度で の泥水温度をどんな作業においても常にハイドレートの 平衡温度より低くするよう, $15 \mathrm{deg} . \mathrm{C}$ の地上泥水を 2.3 $\mathrm{m}^{3} / \mathrm{min}$ のレートで 3 deg.C に冷却する $520 \mathrm{~kW}$ のあの
であった。しかし，リグ上に配置することができないほ ど大きな寸法となったため, 研究チームは, 冷却能力を 極力保ったまま小型化する方法を模索した。なんとかリ グに載せられるサイズとして最終的に設計されたものは $440 \mathrm{~kW}$ となり, やや不足する冷却能力は, ポンプレー トを落としたり，ライザーパイプに沿うブースターライ ンを通して地上泥水を循環することなどによって補うこ とができると判断された。小型化したとは言え, 重量は 70 ton あり, メインデッキと調泥剂ルームのかなりのス ペースを占める寸法であった。プレートタイプの熱交換 器は, 掘削中の泥水と同等のソリッド分を含む泥水を循 環してテストし，実作業に耐えるものであることを確認 した。

\section{3 坑内温度および圧カシミュレーション}

掘削中，コアリング中，あるいは循環中など，いかな る作業においても, その時のハイドレート層の温度と圧 力を予測することができれば非常に有益である。あし， ハイドレートの平衡曲線を超える温度と圧力が予測され れば，地層中のハイドレートが溶けはじめるので注意し なくてはならない。1つの研究チームが坑内温度と圧力 のシミュレーションプログラムの開発を手がけた。この プログラムは WhiteCoal_T と命名され, 次の特徴を有 している (Kawamura. et $a$ l. $^{8)}$ )。

・温度と圧力の両方を同時に求め, それらが八イド レート平衡曲線の内側にあるか外側にあるか判断で きる。

・圧力を求めるハイドロリクス計算において, 泥水の レオロジー特性が温度によって変化することを考慮 している。すなわち泥水が冷却され，その結果粘性 等が上昇することを計算に入れている。

・大水深のライザーパイプに使われる浮力体の熱伝導 率を考慮している。

・温度は, 深度および経過時間軸に対して出力される だけでなく，ある深度での坑壁から奥に向かう水平 距離に対してあ出力される。

・パーソナルコンピュータにおいて, 優れた GUI

(Graphical User's Interface) で簡単に操作できる。

本シミュレーションプログラムは1998年中頃ほぼ完成 し, 以降, これを繰り返し実行させることによって, 坑 内温度を制御する方法および泥水冷却装置の必要性につ いて議論を重ねた。

2.4 コアサンプラー

ハイドレートコアサンプルの採集は本プロジェクトの 最む重要な目的の 1 つである。地下に存在するハイド レートをそのまま分解させずに回収するべく, PTCS (Pressure and Temperature Core Sampler)と呼ばれ 
る新しいコアサンプリングシステムが開発された (Wakishima. et al. ${ }^{9}$ ) (図 4)。採集されるコアの外径は 2-5/8", 長さは $3 \mathrm{~m}, 10-5 / 8^{\prime \prime}$ のコアビットでコアを $3 \mathrm{~m}$ 切削すると, コアはインナーバーレルに格納され，イン ナーバーレルは中の圧力と温度を保持したまま $6-5 / 8^{\prime \prime}$ ドリルパイプ内をワイヤーラインで巻き上げられる。地 上でそれを回収し終わると，空のインナーバーレルがワ イヤーラインによって降下され, 再び $3 \mathrm{~m}$ のコアリン グが絽り返される。イシナーバーレルの圧力保持機構は ボールバルブにより, 低温保持機構はペルティエ効果を 原理とする Battery-powered Thermo-Electric Cooler (TEC) による。また, インナーバーレルは断熱構造に なっており，中の低温が保持されやすくなっている。地 表に上がってきたインナーバーレルは, すぐに室内温度 5 deg.C の専用サービスユニットに入れられ，インナー バーレル内部の温度と圧力を測定し，ガスおよび液体の 採取をしながら圧力を解放した後, コアを取り出す。

このシステムは米国ソルトレークシティの Aumann \& Associates Inc. が設計・製作し, 2 回のフィールド テストが, カナダのマッケンジーデルタ（1998年 3 月） と, 新潟県の石油公団柏崎テストフィールドの実験井 （1998年12月）で実施された。フィールドテストで判明 した問題点はすべて「南海トラフ」の作業開始前に解決 させた。

\section{3. オペレーションの準備}

\section{1 大水深掘削リグの調達}

石油公団主導の元に各共同研究が進められる一方, 基 礎試錐「南海トラフ」の掘削オペレーションを請け負う
石油資源開発(侏)では，その準備作業が進められた。 その中で最む困難を極めたのは大水深掘削リグの確保 であった。当時, 大水深掘削は世界的なブームでありな がら, 太平洋海域で作業している大水深リグはほとんど なく，また，本プロジェクトの作業期間はあまり長くな いため，わざわざ大西洋から日本までリグをあってくる ほどの魅力を多忙なコントラクターに与えることができ なかった。基礎試錐「南海トラフ」の前の年度に掘削さ れる予定であった基礎試錐「三陸沖」を 1 年遅らせて, 両井を同じリグを使って連続的に掘削することにしたの は,リグ調達の可能性を広げる策であった。

唯一, 当時ブラジル沖で稼働していた Falcon Drilling 社のダイナミックポジショニング式ドリルシップ Peregrine-2 が入手可能との情報を得, 交渉を開始し た。かなり老朽化した第 2 世代のリグであったため, 日 本の厳しい気象条件下で問題なく作業できることを確認 するべく, リグインスペクション, ライザーパイプの応 力解析, およびダイナミックポジショニング能力の評価 作業を, 掘削ロケーションにおける気象・海象統計デー 夕および海流調查結果をもとに行った。その結果抽出さ れた, アップグレードすべき装置とそのスケジュールは 主要な契約条件となった。さらには，PTCS コアリング 用 6-5/8"ドリルパイプをスタンドバックさせるための 四本場の改造, 泥水冷却装置の設置場所, および国内で 義務づけられているカッティング搬送システム, 日本の 法規に適合した航路標識灯, 航空障害灯の設置, 鉱山保 安法上のクルー資格等々, 特殊な仕様を多く盛り込んだ 契約を1997年初めにようやく締結することができた。

1999年 1 月, Peregrine-2 がブラジルからシンガポー

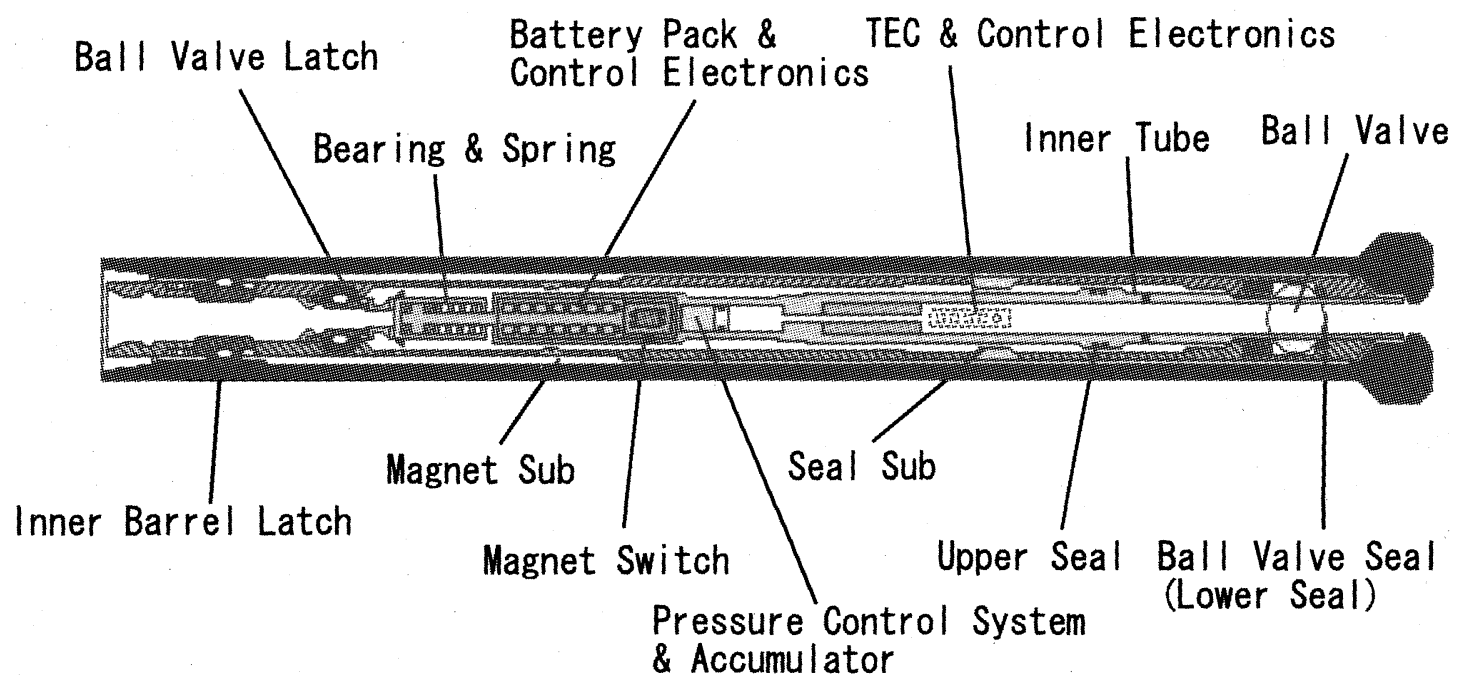

図 4 PTCS (Pressure and Temperature Core Sampler) 概念図 
ルへの長い航海をますなく終えて，オバーホールとアッ プグレードにとりかかろうとする直前, 新しく合併して できた R \& B Falcon Drilling 社は, Peregrine-2 の代 わりに西アフリカで操業していた係留方式の半潜水型リ グ M. G. Hulme Jr. の使用を提案してきた。大水深リグ マーケットが緩み Peregrine 2 の改造にかける費用対効 果が小さくなったことと，ちょうど同社の M. G. Hulme Jr. が入手可能になったことが，その背景にあ る。契約条件について再度大議論の末, 最終的にこの提 案は合意された。直ちにリグインスペクション, 係留解 析, 大型アンカーハンドリングトーイングボートの調 達, 漁業交渉のやり直し, さらには多くの申請書の変更 のすべてを, 掘削作業開始予定日を遅らせることなく迅 速に完了させた。

\section{2 掘削計画}

以下は掘削計画を策定する際に論議された主な検討内 容である。

\subsection{1 シャローガスに対する安全対策}

最む心配されたことは, 深度 $1,240 \mathrm{~m}$ の BSR を掘り 抜くときにシャローガスが噴出する可能性であった。な ぜなら，BSR とは地震波速度の速い上層と地震波速度 の遅い下層との間のコントラストであり，それはとりも なおさずハイドレートが豊富で密度の高い層とフリーガ スが存在し密度の低い層の境目を表すものと思われたか らである。また図 3 を見てあ分かるように，1,240 $\mathrm{m}$ は ハイドレートの平衡点に一致しており, それ以深はメ夕 ンはガスとして存在することを意味する。実はこのフ リーガスも，ハイドレート同様に資源となりえないか調 查の対象とされていた。

当初の基本掘削計画では，八イドレート層直上と思わ れる $1,150 \mathrm{~m}$ あたりにサーフェスケーシングをセット し，ライザーパイプを通して泥水循環しながらハイド レート層の掘削とコアリングを行う予定であった。こう すればマッドロギングデータあカッティングサンプルあ 得られるし，またフリーガスは泥水比重あるいは BOP (Blowout Preventer)によりコントロールできると思 われていた。このため, 循環泥水にハイドレートの生 成・分解抑制機能をむたせたり，循環される泥水の温度 を上げないように冷却する装置を開発することは非常に 重要な課題であった。

しかし，1997年中旬にこの計画を再検討したところ， 浅部の地層が弱すぎるため非常に困難であることが分 かった。1,150 m の地層破壊圧勾配は等価泥水比重で $1.09 \mathrm{SG}$ と計算され，ソリッドを含んだ海水べース泥水 をライザーパイプを通して循環するだけで逸泥する可能 性が非常に高いことが予想された。また，シャローガス
に遭遇した場合，BOP を閉じチョーク/キルラインを通 してキックコントロールしようとすれば, 背圧によって 地層が破壊してしまうことが分かった。ガスがライザー パイプ内に侵入した場合，それがリグに達するころには 著しく膨張し非常に危険な状態をむたらす。海底面で放 散させたほうが，途中の潮流によりリグから十分離れた 場所で海面に到達するため, むしろ安全と思われた。

よって, 大水深でシャローガスの危険がある場合は, ライザーパイプを使わずに掘削するのが最あ安全である との結論に至った。このため, ハイドレート層およびフ リーガス層の調查は, マッドロギングデータとカッティ ングサンプルの取得を断念し，コアと電検だけで評価す ることになった。ライザーパイプなしで電検ッールを坑 内に降げる方法として，6-5/8" OD ドリルパイプを海底 面まで降げて坑にのぞかせ，その中にッールを降げるよ うに計画した。ハイドレート層の調查を終えて, 深部の 油・ガスを探鉱するために，いずれはライザーパイプと BOP をセットしなくてはならないが，その深度は地層 破壊圧が等価泥水比重で $1.25 \mathrm{SG}$ になると予測される $1,600 \mathrm{~m}$ とした。

ライザーパイプを使わないにしても，あし大量のガス が海底面に噴出した場合は, 安全に作業を続けるのは難 しい。セメンチングあうまくいかないであろう。このロ ケーションでそのようなガスが噴出するかどうかを知る ため, メインホールの掘削開始前に，小径 $\left(8-1 / 2^{\prime \prime}\right)$ の パイロット坑を BSR の十分下まで掘削するように計画 された。掘削中は海底面で, ROV (Remotely Operated Vehicle）が坑口を観察し続け，かなりの量のガス 噴出が確認された場合, ここでの掘削は断念し, 別の口 ケーションに移動しなくてはならない。

ここで問題となったのはその判定基準であった。最終 的には図 5 に示すフローチャートにしたがって作業を実 施することにした。すなわち，ガスが噴出した場合，そ れを比重 $1.15 \mathrm{SG}$ の泥水で抑圧できなければ, 重泥で抑 圧後にロケーションを移動する。あしガスフローが $1.15 \mathrm{SG}$ の泥水で抑圧されたならば，その後 $1,600 \mathrm{~m}$ に ケーシングを入れてライザーパイプをセットするまで, 坑内には常に $1.15 \mathrm{SG}$ の泥水を満たすようにして全作業 を行う。このためには，膨大な量のバライトとベントナ イトが必要となる。この基準は, 実際のリグの泥水ミキ シング機器が $1.15 \mathrm{SG}$ の泥水であれば必要なレートで作 泥し続けられるという調查結果に基づいて決められた。

ロケーションを移動しなくてもよいと決定されれば, さらにもう 1 本パイロット坑を掘削する。その目的は, LWD (Logging While Drilling)によって，ハイドレー 卜層およびフリーガス層と思われる深度をおおむね把握 
パイロット坑No. 1

Confirm Pressured Gas
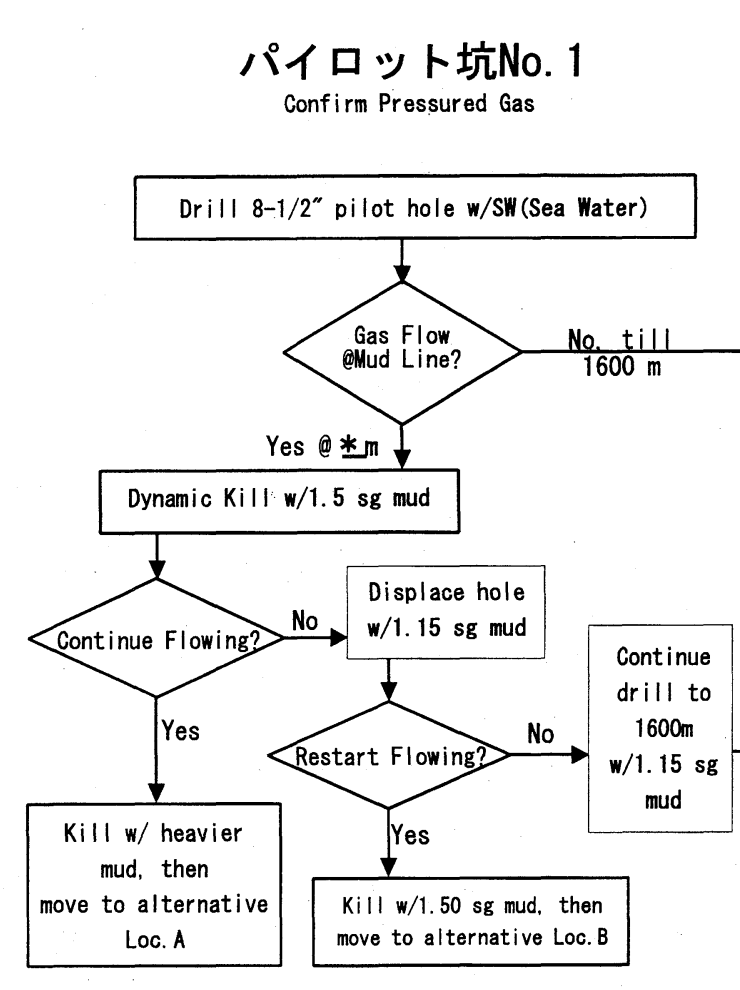
しかし，地層温度が最も高温となる TD $2,800 \mathrm{~m}$ 付近 をライザーパイプを使って掘進中はどうであろうか。小 径の 5 "ドリルパイプ内を高レートでポンプされる泥水 は，途中冷やされる間もなく高温の深部地層を掘削する ビットに至り，暖められてアニュラスを上昇する途中， ケーシングの外側の八イドレート層を溶かしてしまわな いであろうか。ライザーパイプはその外側の冷たい海水 からドリルパイプを隔離するため, 海底付近での冷却効 果は小さい。図 7 はその時の八イドレート層の温度を予 測した WhitCoal_T の出力結果である。 $8-1 / 2$ ” 坑を $2,550 \mathrm{~m}, 2,650 \mathrm{~m}, 2,800 \mathrm{~m}$ 掘進中, あるいは $2,800 \mathrm{~m}$ で コアリングあしくは電検時, 八イドレート層 $1,240 \mathrm{~m}$ における温度の水平分布を示したものである。坑内の泥 水温度は $25 \mathrm{deg} . \mathrm{C}$ を超えるが, その熱は坑井の中心か ら $1 \mathrm{~m}$ 離れるとほとんど影響を及ぼさないことが分か る。ハイドレートの分解は促進反応 (Promoting, reaction）ではなく, 自己保存的反応 (Self-preservation reaction）であることに着目すると，分解は奥へ奥へと進 むのではなく, 坑井中心から約 $1 \mathrm{~m}$ の範囲内で止まる と予想される。この程度の限られた量の分解であれば, ケーシングアニュラスをロ元まで完全にセメントで充填 すれば問題にならないと思われた。よって,この場合に おいても泥水冷却装置は必要ないと判断し，その製作お よび設置はこの段階で取りやめることとなった。

\section{2 .3 泥水計画}

ハイドレート層調査時は, 八イドレート層の温度と圧 カがハイドレートの安定領域内に維持されることが分 かったため，ハイドレートの分解を抑制する泥水はあま り重要でなくなった。実際のところ, ライザーレスで掘 削することが決まった時点で, 高価な泥水を海底面に排 出しながらポンプし続けるのは非現実的なものとなっ

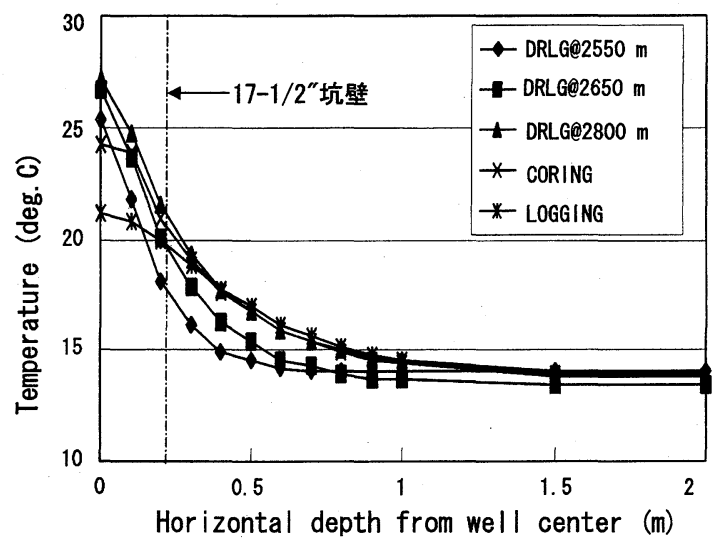

図 7 WhiteCoal_T の出力例 2 8-1/2" 坑掘進中のハイドレート層の温度
た。よって当初計画していた $0.6 \mathrm{wt} \%$ の PVCap を混 入した $\mathrm{NaCl} / \mathrm{KCl} /$ Polymer 泥水は使わないことにし, ホールクリーニングのためにベントナイト泥水を適宜フ ラッシュするが, 基本的には海水をポンプして掘削する という泥水計画に変更された。

ハイドレート層がケーシングで隠され，ライザーパイ プがセットされた後は, 通常の大水深掘削で使われる, 高濃度の $\mathrm{NaCl}$ を混入した海水ベースのポリマー泥水, すなわちハイドレート生成抑制泥水を採用する。

\section{2 .4 ケーシング計画}

図 8 は計画坑内図である。八イドレート層は $10-5 / 8^{\prime \prime}$ 坑でコア掘りを行った後, 17-1/2" 坑に拡掘し, 13-3/ 8 " ケーシングで隠す。通常 $30^{\prime \prime}$ の次は $20^{\prime \prime}$ であるが, クロスオーバージョイントを使うことにより裸坑部の ケーシングは $13-3 / 8^{\prime \prime}$ とした。この非常に重要なケーシ ングセメンチングの成功率を少しであ高めょうとしたか らである。

\section{4. 掘削作業と結果}

\section{1 パイロット坑 No. 1}

リグ M. G. Hulme Jr. は, 基礎試錐「三陸沖」の掘削 を成功裏に終わらせた後, 1999年11月10日「南海トラ フ」のロケーションに到着し, アンカーを 8 点設置し た。まずメインホールの掘削地点を海底面で正確に決め るため, ビット直上にビーコン（音波発信器）を取り付 け，ドリルパイプで海底面直上まで降げた。リグ船底の ハイドロフォン（音波検知器）が示すビーコンとリグの 相対位置と, DGPS (Differential Global Positioning System) が示すリグの絶対位置との関係から，ビーコ ンが予定の座標に来るようにリグをアンカーウィンチ操 作によって動かす。掘削予定地点にビーコンを導いた ら, ビットを着底させ（この時, 掘削地点の水深は 945 $\mathrm{m}$ と記録された。), ROV がその回り 3 箇所にビットか ら $8 \mathrm{~m}$ ずつ離してマーカーを置く。マーカーには ROV が約 $100 \mathrm{~m}$ 離れたところからも検知できるソナーリフ レクターが装備されている。またりグから降げられるい かなる編成も ROV はソナーで検知できるので，これ以 降 ROV は, リグから降げられる編成が，この三角形に 配置されたマーカーに対して, どのような位置にあるか を常に把握することができ，リグではその情報をあっ て，リグ自体をアンカーウィンチで動かし，編成を海底 面の目的位置に着底させることができる。

このようにして，8-1/2" ビットをパイロット坑No. 1 の予定掘削位置すなわち三角形に配置されたマーカーの 中心より WSW 方向に $30 \mathrm{~m}$ のところに導いた。このパ イロット坑は, 掘削中にガスが噴出するかどうかを 


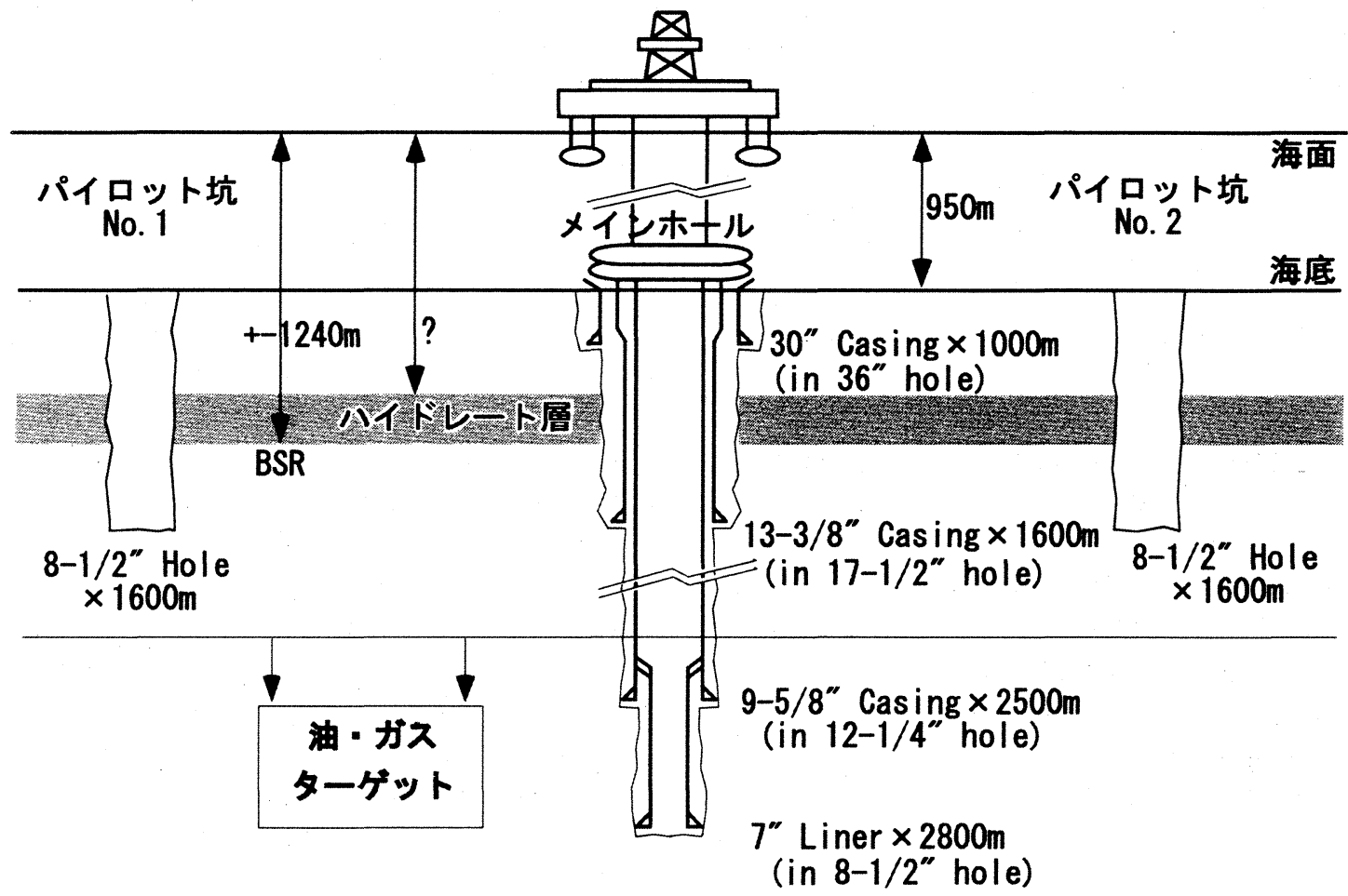

図 8 計画坑内図

ROV で見極めるのが目的であるが，はたして海底に巻 き上がる土砂の中で，ガスを確実に検知できるかどうか が懸念された。そのため，掘削を開始する前に，ROV のソナーがガスをどう検知するかをテストしてみた。 ROV を海面下約 $20 \mathrm{~m}$ の位置に潜らせ，同時にそこま でリグからエアホースを降げ，エアバブルを強くしたり 弱くしたりして，ROV のテレビカメラとソナーにどう 映るかを確認した。その結果, 微弱なバブルでも ROV ソナーに音波異常として確実に検知されることが分かっ た。

1999年11月13日，パイロット坑 No. 1 が掘削開始され た。ガスが噴出した場合に備えて，泥水タンクには $1.50 \mathrm{SG}$ の高比重抑圧泥水を満たし，またバルクタンク にはバライトを満載した。陸上資材基地とサプライボー トはさらなる補給に備えた。リグではセーフティーミー ティングを開き，ガスが噴出した場合のダイナミックキ ルの手順をクルーに周知徹底させた。主要な作業員は $\mathrm{ROV}$ が映し出す海底坑口部の映像とソナースクリーン を見続けた。最もガス噴出の可能性の高い深度 $1,240 \mathrm{~m}$ 近辺では，掘進率を $1 \mathrm{~m} / \mathrm{min} に$ 抑え，細心の注意を 払って監視した。1,600 m まで掘削したが，結局，ガス バブルは確認されなかった。ビットを揚管後，ROVは
さらに 1 時間坑口で観察を続けたが，ガスバブルは全く 見られなかった。つまり,このロケーションでは, 以降 の作業を安全に計画どおり遂行できることが分かった。

4.2 パイロット坑 No. 2

続いて，パイロット坑 No. 2 の掘削に移った。このパ イロット坑は, LWD でハイドレート層およびフリーガ ス層と思われる深度を把握し，この後のメインホールで のコアリング区間を决定することが目的である。 RABCDR-CDN からなる LWD ッール（ソニックッールは 入手できず。）を 8-1/2"ビット直上に取り付け，この編 成を前述の方法でパイロット坑 No. 1 とは反対方向にメ インホールから $30 \mathrm{~m}$ 離れた箇所に導き, 掘削を開始し た。この方向は，地層の走向と一致させている。各井で 同じ地層が出現する深度の差を最小にするためである。 LWD ログの精度を上げるため，掘進率は $0.5 \mathrm{~m} / \mathrm{min}$ にコントロールしたので, $1,486 \mathrm{~m}$ に到達するのに 30 時 間かかり，そこで抑留された。数度にわたり高比重高粘 性泥水をポンプしたところ，12時間後に離脱に成功し た。コアリング区間を決めるための情報はすでに取得で きていたため，この深度で掘進を中止した。ここであ ROV は海底面で坑口の監視を続けたが，ガスバブルは 見られなかった。 
図 9 はパイロット坑No. 2 で得られた LWD ログであ る。1,183 m から $1,207 \mathrm{~m}$ にガンマレイが低く, 比抵抗 の著しく高い層が何枚かある。ドリリングパラメータを 記録するドリラーのログにはこれらの深度で高いトルク が記録されている。これらは，ハイドレートを多く含む 砂層の存在を示唆するあのと考えられ，メインホールの コアリング区間を次のように定めた。PTCS の使用は最 あ重要な層に限定した。

・1,110 m 1,175 m : 通常のコアリングシステムに よるコアリング

・1,175 m 1,254 m : PTCS でのコアリング

・1,254 m〜1,272 m : 通常のコアリングシステムに よるコアリング

\section{$4.3 \times$ メンホール}

海底面上に設置された 3 個のマーカーの中心に $36^{\prime \prime}$ ビットを導き，1999年11月18日メインホールの掘削を開 始した。996 m（海底面下 $51 \mathrm{~m}$ ）に 30 ” ケーシングを セットした後，10-5/8” 坑を $1,110 \mathrm{~m}$ まで掘進し，コア リングが行われた。

\subsection{1 コアリング}

1,110m から 1,175m までは, Security DBS 社の従
来型のコアバーレルが使用された。外径 4 " で長さ $9 \mathrm{~m}$ のコアサンプルは 8-1/2" コアビットで切削され, 超軟 質層用に設計されたクラムシェル型キャッチャ一 “PosiClose ${ }^{\mathrm{TM}}$ によって捕獲される。最初の 2 回はそ れぞれ $9 \mathrm{~m}$ のコア回収に成功した。しかし，3回目拉よ び 4 回目で一度に $18 \mathrm{~m}$ のコアが回収できるようにコア バーレルを 2 本つないで降げたところ，それぞれ $42 \% お ~$ よび $28 \%$ の低回収率となった。 5 回目は再度コアバーレ ル1本で $9 \mathrm{~m}$ のコアを切削したところ回収率は $75 \%$ に上 がった。地質はほとんどシルトとクレイで，数枚の薄い 砂を挟んでいた。これらのコアにハイドレートは目視で きなかったが， 1,128m 以深のコアが入っていたバーレ ル内にあった海水にはガスバブルが観察されている。

$1,175 \mathrm{~m}$ から $1,254 \mathrm{~m}$ では, 圧力と温度を保持したコ アサンプルを採取するため，PTCS が使われた。ッール ジョイントの内径が $5.906 "$ という特別仕様の 8-5/8" OD ドリルカラーと 6-5/8" OD ドリルパイプが組まれ, この中をインナーバーレルがワイヤラインによって揚げ 降げされる。 $3 \mathrm{~m}$ のコアを切削しては，それを密封した インナーバーレルをワイヤラインで取りに行き，地上で 回収した後，空のインナーバーレルをまたワイヤライン
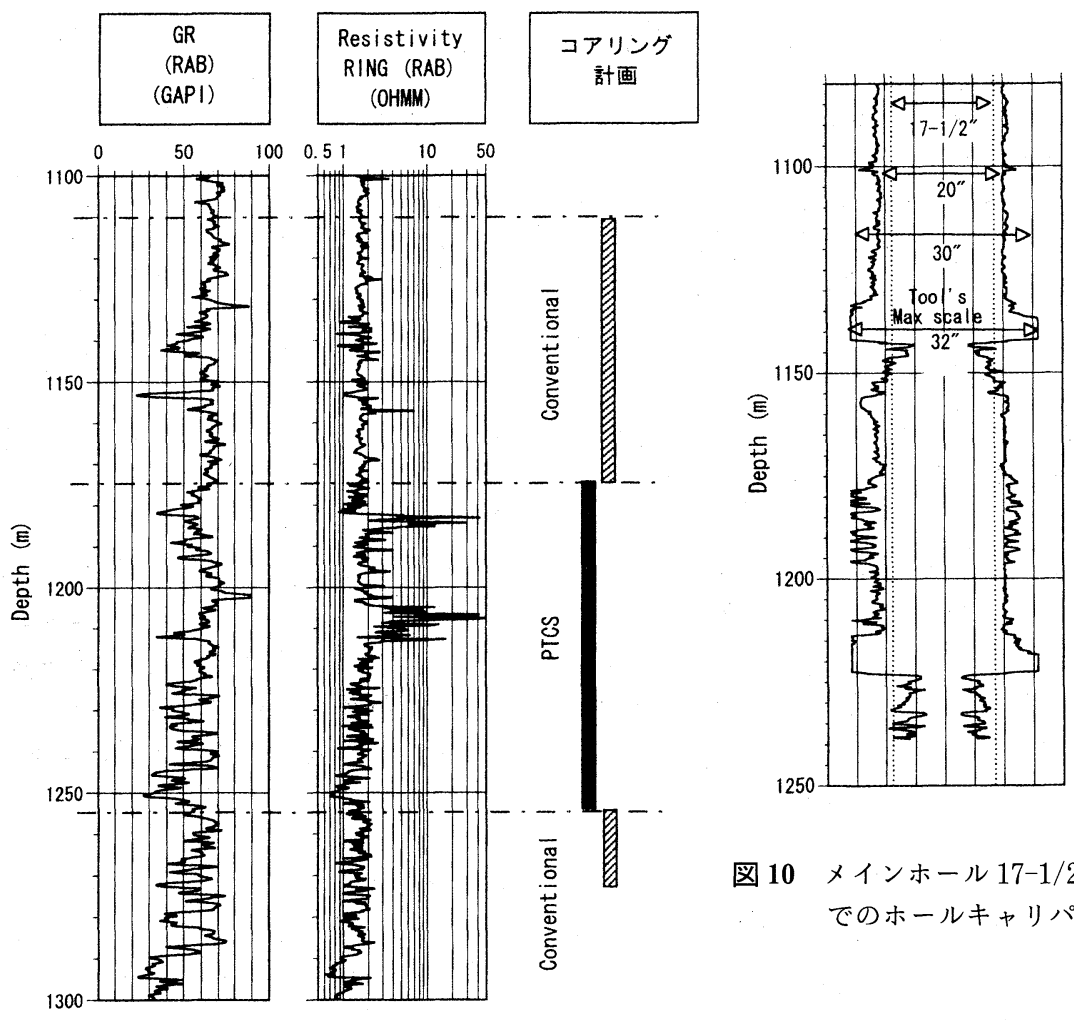

図 10 メインホール 17-1/2" 坑 でのホールキャリパー 
で置いてくるという 1 サイクルに $4 \cdot 5$ 時間かかるため, この間での計27回の PTCS コアリング作業に 5 日間を 費やした。27回の平均コア回収率は37\%であった（79 m コアリングし $29 \mathrm{~m}$ を回収)。温度と圧力の保持機構は それぞれまれに効いていなかったあのがあった。

PTCS で回収されたコアの多くはシルトとクレイであ るが，それらに挟まれた何枚かの薄い砂（厚くても $2 \mathrm{~m}$ 程度）には非常に興味深い特徴が見られた。まずコアを 取り出すと砂の表面からガスバブルが湧出した。このガ スは分析の結果メタンであることが分かった。またこの 砂の内部に温度計を突き刺すと -2 deg.C から $-3 \mathrm{deg}$. Cの值を示した。これは中で吸熱反応が進行しているこ とを意味している。さらにこの砂サンプルの孔隙中の塩 分濃度を測定すると 100 から $200 \mathrm{mMol}$ と異常に低い值 を示した。通常のあのは海水と同じ $550 \mathrm{mMol}$ 位であ る。これらの現象は, 砂の孔隙内にハイドレートが存在 しそれが溶けていることを示す。特に $1,181 \mathrm{~m}$ と 1,204 $\mathrm{m}$ の砂サンプルが顕著で, その低い塩分濃度の值から, ハイドレートは孔隙の $80 \%$ を占めていたと計算された。 これらの深度はパイロット坑 No. 2 の LWD ログ（図 9 ）で記録された異常に高い比抵抗の深度と一致してい る。これらの深度で, コアリング中に高いビットトルク が記録されていることと，コアの回収率が高いのは，お そらく, ハイドレートを含む砂層は, In-situ の状態で はかなり固く締まっているからと思われる。

PTCS でのコアリング後, あう2 回, 従来型コアバー レルを使ったコアリングを $1,254 \mathrm{~m}$ から $1,272 \mathrm{~m}$ で行 い, 計 $5.5 \mathrm{~m}$ のシルトサンプルを回収した（回収率 30\%)。期待された砂層が回収できなかった理由は，お そらく，それがハイドレートを含まないのであまりにも 軟らかかったからと推定される。

すべてのコアサンプルはリグで記載を行った後, 直ち に地上の各研究所に送られ，各種分析および計測に供さ れた。ハイドレートを特に多く含むコアサンプルについ ては, 圧力容器に収め, さらにそれをドライアイスで包 んで輸送した。実験室でのコア分析結果の 1 つとして, メタンガスの炭素同位体を分析したところ，このガスは 微生物起源 (biogenic) であることなどが報告されてい る。

ROV はここであコアリング作業中，常に坑口を監視 し続けたが，ガスバブルは観察されなかった。

\subsection{2 電 検}

10-5/8" 坑を $13-3 / 8^{\prime \prime}$ ケーシングセット深度の 1,600 $\mathrm{m}$ まで掘削後, $17-1 / 2^{\prime \prime}$ 坑に拡掘する前に電検が行われ た。ライザーパイプがないので， 6-5/8”ドリルパイプ を $30^{\prime \prime}$ ケーシングにのぞかせて, その中に電検ッールを
降下させた。しかし，ッールは $1,140 \mathrm{~m}$ 以深どうして も降がらなかった。

ビットを降げてワイパートリップと循環を行った後, 再度試みたがッールは同じ深度でつっかえた。17-1/2" 坑に拡掘後, 再度試みたが, 坑内状況は拡掘前とほぼ同 様であった。今度は, サイドェントリーサブを取り付 け，6-5/8"ドリルパイプの内部にッールをセットして ドリルパイプと電検ツールをとあに坑底まで降げた後, ドリルパイプと電検ツールを交互に揚げて測定するよう 試みた。しかし，ドリルパイプ自体 $1,260 \mathrm{~m}$ でっっか えて降がらなかった。結局, HALS-DSI-EMS-GR を $1,260 \mathrm{~m}$ 以浅で測定したにとどまった。ガンマレイと比 抵抗の測定結果はパイロット坑 No. 2 の LWD 結果と同 様であった。それ以外のログは坑径の異常拡大により デー夕の精度が悪く, 地層評価に使えるものではなかっ た。図10はこのとき得られたキャリパーログである。 何ヶ所かキャリパーッールの最大径 32 をを超えたところ があるが，その深度はメタンハイドレートをあまり含ま ない砂層に対応する。八イドレートを多く含む砂層はそ れほど拡大していない。八イドレートが溶ける温度にな らなかったからであろう。このように坑径が著しく大き いところとそうであないところが交互に出現する理由 は，ハイドレートを含まない未固結層とハイドレートを 多く含む固結層の互層を, 時間をかけてゆっくりとコア リングしながら掘り抜いたためと思われる。

\subsubsection{3-3/8" ケーシングセメンチング}

1999年12月 13 日, $1,613 \mathrm{~m}$ に 13-3/8" ケーシングを セットし，ハイドレート層を隠すセメンチングを行っ た。Dowell Schlumberger 社の DeepCRETE ${ }^{\mathrm{TM}}$ セメン ト（スラリー比重 $1.40 \mathrm{SG}$ ) でフルホールセメンチング を行った。キャリパーログを見た後直ちに，追加分のセ メントおよび添加剂を発注し， スラリー $110 \mathrm{~m}^{3}$ 分を確 保した。これはリグタンクのすべてを使った最大量であ る。セメンチング作業時後半, ROV により海底面への セメントリターンが確認されている。しかし, BOP と ライザーパイプを設置後に Cement Bond Log (CBL) を測定したところ， 1,305 $\mathrm{m}$ より上にセメントが効いて いる兆候は全く見られなかった。続いてVSP (Vertical Seismic Profile) を予定どおり行ったが, セメントボン ド不良のためデータの質は悪かった。ROVによって確 認されたセメントの海底面へのリターンは，不規則に拡 大した坑内をチャンネリングして上昇したセメントの一 部であったと思われる。

早速, 補修セメンチングをするべきかどうか議論され たが, 結論は, 補修セメンチングは行わずに深部の掘削 を行うことになった。確認されたハイドレートは何枚か 
の薄い砂層の孔隙を満たす程度のあのであり, それがこ れからの掘削中に坑壁から奥数 $10 \mathrm{~cm}$ の範囲で溶けた としてあ, あと 1 ヶ月で終わる掘削作業を妨げるあので はないと判断したからである。

\subsubsection{TD (Total Depth) までの掘削}

BOP およびライザーパイプをセットし，計画どうり， 深部第三紀層の油・ガスを探鉱するため $2,800 \mathrm{~m}$ まで 掘削した。しかし, 油・ガス兆がなかったので, そのま ま 8-1/2" 坑を $3,300 \mathrm{~m}$ まで延長した。 $3,300 \mathrm{~m}$ で最終 電検を行った後, 本井は2000年 1 月20日廃坑された。

$2,200 \mathrm{~m}$ 以深掘進中, 海底面の $13-3 / 8^{\prime \prime}$ ケーシングの 外側から弱いガスバブルが時々間欠的に出ていることが ROV によって観察されている。そして, BOP の下側の ガスが留まりやすいような箇所にシャーベット状の八イ ドレートが生成されているのをテレビモニターが映して いる。ROV は以降毎日それをマニュピュレーターで搔 き落としたり, ジェットポンプで吹き飛ばしたりして除 去に努めた。またウェルヘッドと BOP を接続する H 4 コネクターに通ずるポートにグリコールを注入し，切り 離すときに問題が生じないようにした。これらの作業の せいか, 坑口装置に機能の異常はなかった。このガス は, セメントで隠しきれなかった八イドレート層が深部 から上がってくる泥水の熱で溶けて発生したものであろ う。本井廃坑後, このガスは完全に止まっている。

\section{5. 追加調查}

リグを復員させる前に, 同ロケーションで八イドレー ト層だけをターゲットとした追加調查井をもう 3 坑掘削 することが決められた。図11に各坑井の位置を示す。各 井の目的を下に記す。

・追加調查井 No. 1 : メインホールから $10 \mathrm{~m}$ 離れた 地点で 10-5/8" 坑を $1,300 \mathrm{~m}$ まで掘削し, メイン ホールで達成できなかった各種の電検を行う。

・追加調查井 No. 2 : メインホールから $20 \mathrm{~m}$ 離れた 地点で 10-5/8" 坑を $1,149 \mathrm{~m}$ まで掘削した後, $1,149 \mathrm{~m}$ から $1,223 \mathrm{~m}$ まで PTCS コアリングを行 う。実験室での分析用コアサンプルをより多く採集 するためである。

・追加調査井 No. 3：メインホールからアップディッ プ方向 (SSE) に $100 \mathrm{~m}$ 離れた地点で 10-5/8" 坑を $1,300 \mathrm{~m}$ まで掘削して, 電検を行う。ハイドレート 層がアップディップ位置でどのように変化して現れ るかを調查するためである。

\section{1 追加調查井 No. 1}

メインホールで坑径が著しく不規則に拡大し電検ッー ルを降げることができなかったのは, 軟硬の互層をゆっ

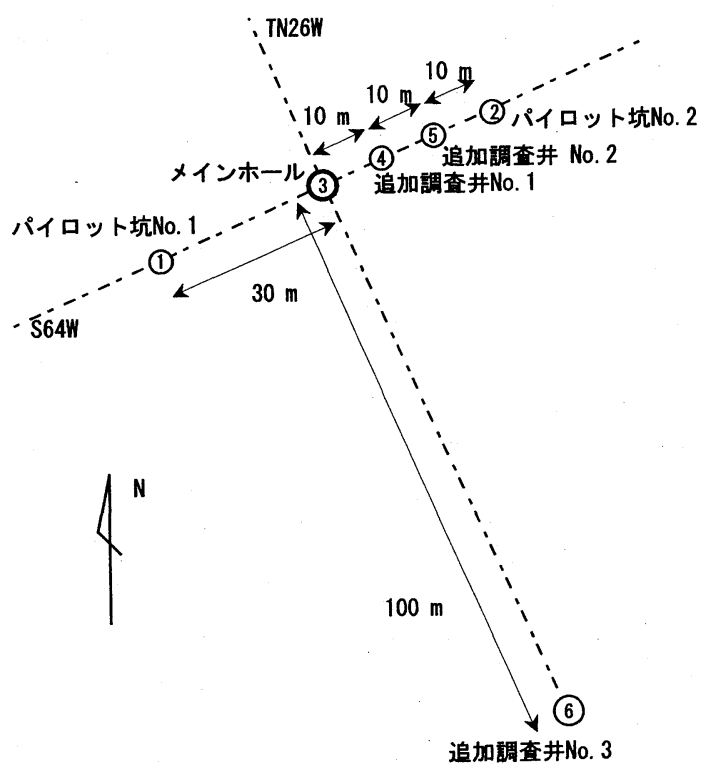

図 11 各井位置図

くりとコアリングしたからであると判断し，ここでは速 やかに掘削して直ちに電検を行うべく努めた。2000年 1 月22日, 追加調查井 No. 1 は 10-5/8” ビットでの掘削を 開始し, 海底面 $(945 \mathrm{~m})$ から $1,300 \mathrm{~m}$ までを 5 時間で 掘削した。坑内を高粘性泥水で満たした後, 6-5/8"ド リルパイプを海底面下 $30 \mathrm{~m}$ まで降げ，その中に電検 ッールを降げていった。しかし, ッールはドリルパイプ を数m出たところでっっかえてしまった。ドリルパイプ 下端の位置を何回か変えて試みたが, ッールは常にドリ ルパイプを出るとすぐに降がらなくなった。電検ッール

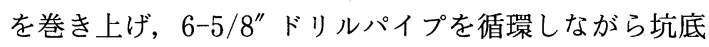
$1,300 \mathrm{~m}$ まで降げ, 高粘性泥水で坑内を満たした後, $1,000 \mathrm{~m}$ までゆっくりと揚管し, 再度電検ツールをドリ ルパイプ内に降げていったところ, ッールは初めて坑底 まで降がった。次の 5 runすべてを測定し, ハイドレー 卜層に関する大変貴重な電検デー夕をようやく得ること ができた。

DSI-GR-EMS
HALS-GR
VSP (Zero offset, 71 levels)
FMI-GR
CMR-GR

図12に主なログを並べて示す。一番左のキャリパーロ グを見ると，依然坑径は部分的に拡大しているがメイン ホールの（図10）よりはずっと良い。メインホールで採 集したコアのうちハイドレートを多く含むサンプルの深 

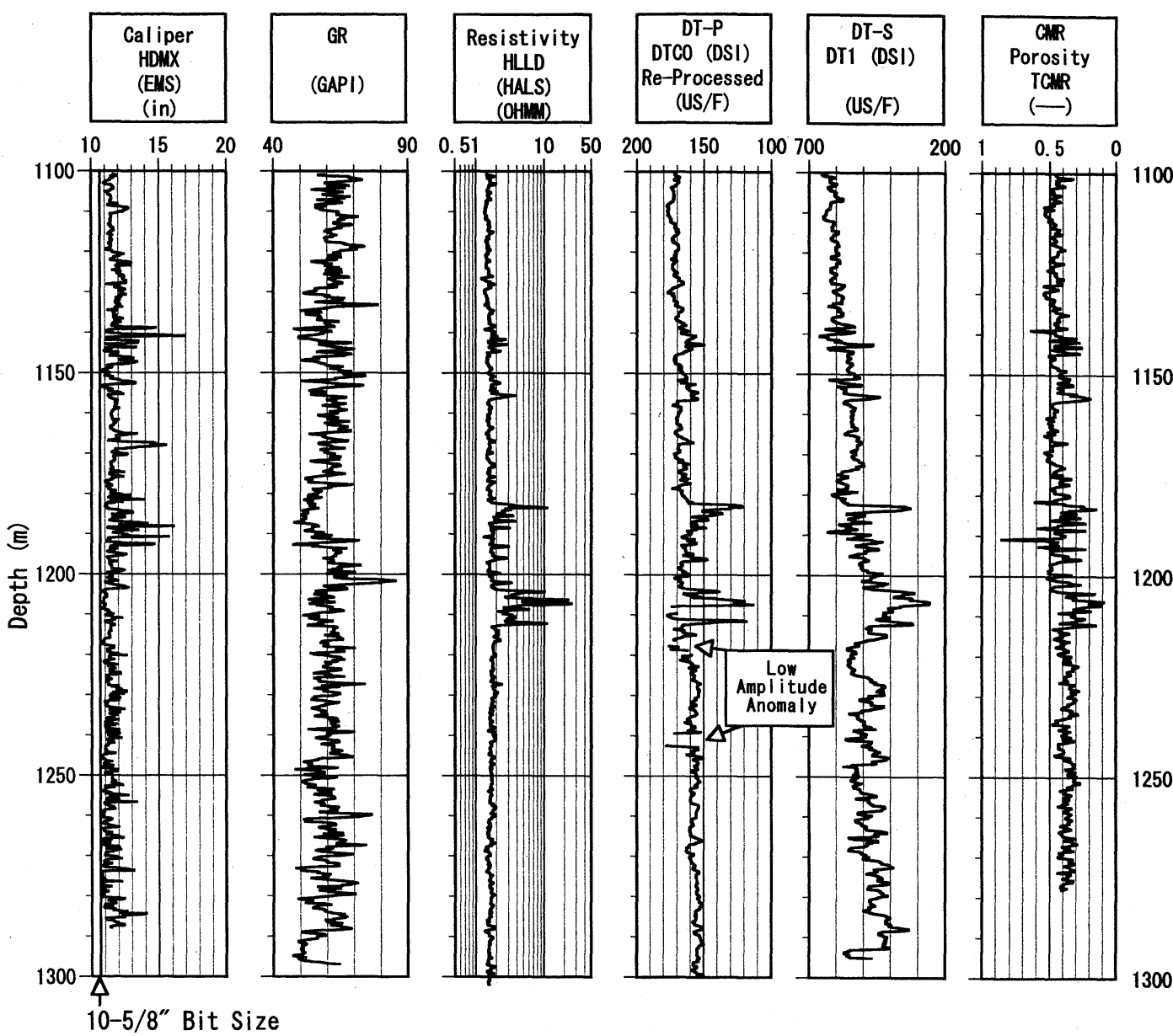

図 12 追加調查井 No. 1 での主な電検ログ

度では, 著しく高い比抵抗とともに, 高い音波速度と低 いCMR 孔隙率が観察された。そのような層の厚さは FMI ログから合計で $20 \mathrm{~m}$ と数え上げられた。また，こ れらのログから計算されたハイドレート含有量は最大で 孔隙中の $75 \%$ と報告され，コアサンプルの塩分濃度異常 から計算された $80 \%$ という值に近いあのとなった。な お，砂層の平均孔隙率は $36 \%$ と評価された。

注目すべきは，音波検層口グにおける $1,215 \mathrm{~m}$ と 1,240m あたりに見られる P 波の異常減衰である。VSP においてむ両深度で低速度の層を確認しており，うち 1 つは震探断面図で BSR として表わされている（図 2 )。 これらの現象はフリーガスの存在を示唆するあのであ る。実際，ガスはこれらのログに表れる程度に存在した のであろう。しかし，掘進中に噴出するほどのものでは なかったというのが事実である。

\section{2 追加調查井 No. 2}

2000年 1 月 25 日, リグをあう $10 \mathrm{~m}$ 動かし, 追加調查 井 No. 2 の掘削を開始した。 $1,149 \mathrm{~m}$ まで 10-5/8” 坑を 掘削後，PTCSによるコアリングを行った。コアリング 区間はそれまでに得られたデー夕をあとに厳選された。 すなわち, 1,149 m〜1,158 m (3 run), 1,178 m〜1,187 $\mathrm{m}$ (3 run), 1,199 $\mathrm{m} \sim 1,214 \mathrm{~m}$ (5 run), 1,220 $\mathrm{m} \sim$ $1,223 \mathrm{~m}$ (1 run), 計 $36 \mathrm{~m}$ (12 run) が選ばれた。コアリ ング区間以外は，コアリング編成のまま，インナーバー レルをセットせず，コアビットで掘削した。地層が軟ら かいことと，コアビットが肉厚であるためそれが可能で あった。2.5日かけて，計 $16.9 \mathrm{~m}$ のコアを回収し（平 均回収率47\%)，実験室にさらなる貴重なサンプルを提 供することができた。1,153m のコアサンプルに目視で きるハイドレートの結晶を確認している。 


\section{3 追加調査井 No. 3}

リグをアップディップ方向 (SSE) に $100 \mathrm{~m}$ 移動し, 2000年 1 月 29 日，追加調査井 No. 3 を掘削開始した。 $1,300 \mathrm{~m}$ まで 6 時間で掘削した後, 追加調查井 No. 1 で 得られた経験をあとに，6-5/8"ドリルパイプをまず坑 底まで降げ, 循環して高粘性泥水で坑内を満たし, $1,000 \mathrm{~m}$ までゆっくりと揚管した。そうして電検ツール をドリルパイプ内に降げていったところ, 次の 6runす べて坑底まで問題なく降げることができた。

DSI-GR-EMS

HALS-GR

VSP (Zero offset, 60 levels)

FMI-GR

CMR-GR

MDT-GR

アップディップ方向に掘削されたため，各地層は追加 調査井 No. 1 よりも $9 \mathrm{~m}$ 浅く現れた。しかし，ハイド レート層基底と思われる高比抵抗層群のボトムは追加調 查井 No. 1 と同様 $1,213 \mathrm{~m}$ であった。つまり新しい高比 抵抗の砂層が基底に出現した。また高比抵抗層群のトッ プは追加調査井 No. 1 および No. 2 より $6 \mathrm{~m}$ 浅い 1,135 $\mathrm{m}$ であった。追加調査井 No. 1 では八イドレートを含ん でいたのに，ここでは高比抵抗を示さなかった砂層も 2 〜 3 枚あった。音波検層において, 追加調查井 No. 1 と 同様ここでも $1,215 \mathrm{~m}$ と $1,240 \mathrm{~m}$ あたりに $\mathrm{P}$ 波の異常 減衰が見られている。

これをあって, リグ M. G. Hulme, Jr. は 8 基のアン カーを回収し，2000年 2 月 5 日にシンガポールに向けて 復員を開始した。

\section{6. 結 論}

（1）海洋で世界初のメタンハイドレートを対象とした 探鉱が，日本の南海トラフ，水深 $945 \mathrm{~m}$ の地点で 実施され，海面下 $1,135 \mathrm{~m}$ から $1,213 \mathrm{~m}$ 間の何枚 かの砂層の孔隙にメタンハイドレートの存在を確認 した。ハイドレートの総量は特に大きなものではな かったが，大水深海域でその量を評価する手法は確 立された。

（2）心配されたシャローガスの噴出はここではなかっ た。しかし，それに対して準備した安全対策は，今 後の大水深掘削, とりわけ BSR を掘り抜こうとす るオペレータに有効である。

(3) 新たに開発したコアリングシステム「PTCS」 と, 坑内温度压力シミュレーションプログラム 「WhiteCoal_T」は，ハイドレートの探鉱に有用な ッールである。
（4）ハイドレートを含まない未固結な層とハイドレー トを多く含む固結した層との互層を，時間をかけて 掘削すると，坑径が著しく大きいところとそうでな いところが交互にでき，電検やケーシングセメンチ ングは大変困難になる。このような層を掘り抜く時 は，できるだけ速やかに掘削し，すぐにケーシング で覆うべきである。

(5) ハイドレートの存在を調査する最む簡単な方法は LWD である。パイロット坑 No. 2 で得られた LWD ログは，メインホールで得られたコアサンプ ルとよく対応する。音波検層ツールを備えた LWD を使えばより確実に評価できる。

（6）震探断面図に招ける BSR の深度は，音波検層口 グにおける $\mathrm{P}$ 波の異常減衰深度と一致した。フ リーガスはハイドレート層の直下にログに表れる程 度に存在したのであろうが，掘進中に噴出するほど のあのではなかった。

\section{7. 今後の計画}

メタンハイドレートの資源としての可能性を評価する には，量と生産性の両方を評価しなくてはならない。

量を評価するには，より多くの坑井を掘削して広がり を確認しなくてはならない。その際，本プロジェクトで 確立された手法を駆使することはいうまでもない。また それら新しいロケーションの選定にあたっては，本井で 得られたすべての地質情報を基に，さらなる震探デー夕 の取得と解釈によって BSR をより確実に特定すること が必須である。

生産性を評価するために，ハイドレートの分解をシ ミュレーションするプログラムが現在開発されている (Masuda. et $a l .^{10) \sim 12)}$ )。これに入力するパラメータとし て，本井のコアサンプルや電検で確認されたハイドレー 卜層の物性值が使われるのは当然である。さらに，石油 公団は2002年 2 月にカナダのマッケンジーデルタで, GSC (Geological Survey of Canada), USGS (United States Geological Survey), USDOE (United States Department of Energy), および GFZ (GeoForschungs Zentrum, Germany) と共同で，永久凍土下のメタン八 イドレートの生産テストを計画している。その結果はシ ミュレーションプログラムの検証にも使われる。

メタンハイドレートの資源としての可能性を調査する 我が国の計画は，経済産業省主導のもと前進しつつあ る。

\section{謝 辞}

経済産業省，石油公団，および 5 年間の共同研究に従 
事された民間10社から，発表の許可を頂きお礼申し上げ たい。また，本プロジェクトを成功に導いたすべての 方, とりわけ準備段階において斬新な計画の 1 つ 1 つを 決定した基礎試錐技術検討委員会およびメタンハイド レート開発推進委員会の委員の方々, 共同研究に取り組 まれた方々, また国内最初の大水深オペレーションに終 始現実的な助言をくれたコンサルタントMr. Riley Sheffield, および特殊なウエルコントロール計画をともに 考えてくれたコンサルタント Mr. Colin Leach に感謝す る。実作業においては, 誰も経験したことのない新しい 作業のすべてを常に最善の方法で遂行した M. G. Hulme Jr.のリグクルー, そして昼夜海底面で我々の安 全を見守り続けてくれた Oceaneering 社の ROV ク ルーにむ心から感謝する。

最後に, 本邦訳を石油技術協会誌に掲載することを許 可して下さった OTC に謝意を表す。

\section{SI 単位換算係数}

$$
\begin{aligned}
& \mathrm{SG} \times 1.0 \mathrm{E}+3=\mathrm{kg} / \mathrm{m}^{3} \\
& \text { Inch (本文中は" で表示) } \times 2.54 \mathrm{E}-2=\mathrm{m} \\
& \text { 参 考 文 献 }
\end{aligned}
$$

（OTC には下記の英文で発表されているものだけを紹 介した。)

1) Kvenvolden, K. A., 1993: A primer on gas hydrates. The future of energy gases. U.S. Geological Survey Professional Paper, 1570.

2) Satoh, M., Maekawa T. and Okuda Y., 1996 : Estimation of amount of methane and resources of natural gas hydrates in the world and around Japan. Jour.Geol. Soc. Japan, 102, 959.

3) Ashi, J. and Tokuyama, H., 1997 : Cold seepage and gas hydrate BSR in the Nankai Trough. Proceedings of the International Workshop on Gas Hydrate Studies, the Second Joint Japan-Canada Workshop, 256.

4) Ohara, T., 1998 : Drilling operation penetrating methane hydrate. Proceedings of the International
Symposium on Methane Hydrates, JNOC-TRC, Chiba, Japan, 87.

5) Maeda, Y and Okui, T., 1998 : Influence of additives on kinetics of methane hydrates. Proceedings of the International Symposium on Methane Hydrates, JNOC-TRC, Chiba, Japan, 269.

6) Okui, T., Maeda, Y., Konno, S., 1998 : Kinetic control of methane hydrates in drilling fluids. Proceedings of the International Symposium on Methane Hydrates, JNOC-TRC, Chiba, Japan, 293.

7) Ichikawa, Y., Nonaka, A., Urano, T., Yasuhara Y., 1998 : Development of mud cooling system installed on-board of drill ship. Proceedings of the International Symposium on Methane Hydrates, JNOC-TRC, Chiba, Japan, 161.

8) Kawamura, K., Ichikawa, Y., Urano, T., Chiang J. H., 1998 : Development of downhole temperature and pressure simulation program for drilling/completing natural methane hydrate. Proceedings of the International Symposium on Methane Hydrates, JNOC-TRC, Chiba, Japan, 149.

9) Wakishima, R., Imazato, M., Nara, M., Aumann, J. T., Hyland, C., 1998 : The development of a pressure temperature core sampler (PTCS) for the recovery of in-situ methane hydrates. Proceedings of the International Symposium on Methane Hydrates, JNOC-TRC, Chiba, Japan, 107.

10) Masuda, Y., Naganawa, S., Ando, S., and Sato, K., 1997 : Numerical calculation of gas-production performance from reservoirs containing natural gas hydrates. SPE38291,

11) Masuda, Y. et al., 1998 : Development of a numerical model for predicting hydrate - decomposition behavior in reservoirs. Proceedings of the International Symposium on Methane Hydrates, JNOCTRC, Chiba, Japan, 185.

12) Masuda, Y. et al., 1999 : Modeling and experimental studies on dissociation of methane gas hydrates in berea sandstone cores. Proceedings of the third International Gas Hydrate Conference, ParkCity, Utah, USA. 